\title{
EVALUASI PEMILU SERENTAK TAHUN 2014 DI PROVINSI LAMPUNG
}

\author{
Rudy \\ Fakultas Hukum Universitas Lampung. \\ rudy.1981@fh.unila.ac.id \\ Martha Riananda \\ Fakultas Hukum Universitas Lampung \\ Martha.rianand@fh.unila.ac.id \\ Utia Meylina \\ Fakultas Hukum Universitas Lampung
}

\begin{abstract}
This research aims to find a model of electoral implementation simultaneously in Indonesia, through the elections of regional heads of Lampung province as a form of legislative elections, and the election of regional heads were held simultaneously on April 9, 2014. This research uses case approach and statute approach. The research found that there were drawbacks on the election of regional heads in Lampung province, one of them was the postponement of the election.
\end{abstract}

Keywords: Election Evaluation of 2014, and Lampung Province

\section{abstrak}

Penelitian ini bertujuan untuk mencari sebuah model pelaksanaan pemilihan umum serentak di Indonesia melalui pemilihan umum Kepala Daerah Provinsi Lampung sebagai bentuk pelaksanaan pemilu legislatif dan pemilu kepala daerah yang dilaksanakan serentak pada tanggal 9 April 2014. Penelitian ini menggunakan pendekatan kasus (case approach) dan pendekatan undang-undang (statute approach). Penelitian ini menemukan bahwa pelaksanaan pemilu kepala daerah provinsi Lampung terdapat kelemahan-kelemahan salah satunya adalah penundaan pelaksanaan pemilu.

Kata Kunci: Evaluasi Pemilu 2014, dan Provinsi Lampung

\section{A. Pendahuluan}

Pasca perubahan UUD 1945, kedaulatan dilaksanakan dalam bentuk kekuasaan penyelenggaraan negara. Kekuasaan tersebut dijalankan sesuai dengan wewenang lembaga-lembaga negara yang diatur UUD 1945. Selain oleh lembaga negara, kedaulatan penyelenggaraan negara juga dilaksanakan oleh rakyat sendiri yang perwujudannya melalui pemilu, salah satunya untuk 
memilih kepala daerah dan wakil kepala daerah, sebagai gubernur/wakil gubernur yang akan memerintah di provinsi, bupati/wakil bupati yang akan memerintah di kabupaten serta walikota/wakil walikota yang akan memerintah di kota. Hal ini diharapkan agar kepala daerah yang terpilih sesuai dengan kehendak bersama masyarakat berdasarkan pada misi, visi, program serta kualitas dan integritas calon. Nantinya, hasil pemilihan kepala daerah sangat penting bagi terlaksananya otonomi daerah, karena kepala daerah yang terpilih merupakan penggerak utama keberhasilan terwujudnya penyelenggaraan pemerintahan daerah berdasarkan prinsip otonomi daerah.

Bertolak dari itu, Lampung pada tahun 2013 melaksanakan pemilihan umum gubernur namun hal ini tidak sesuai dengan yang diinginkan. Pelaksanaan pemilihan gubernur ini telah mengalami penundaan yang yang sangat mencengangkan yakni sampai ditunda hingga tiga kali yakni pada tanggal 2 Oktober 2013, kemudian dimundurkan menjadi 2 Desember 2013, di mundurkan lagi pada tanggal 27 Februari 2014 dan pada akhirnya ditetapkan pelaksanaan Pemilihan Gubernur berbarengan dengan Pemilihan Legislatif yang kemudian dilaksanakan pada tanggal 19 April 2014. Hal inilah yang memerlukan evaluasi mendalam mengapa sampai 3 kali penundaan danevaluasi-evaluasi yang lain yang berhubungan mengenai pelaksanaan pemilihan umum gubernur di Provinsi Lampung.

\section{B. Pembahasan}

\section{Desentralisasi dan Otonomi Daerah}

Negara Kesatuan Republik Indonesia (NKRI) telah mengalami berbagai macam perubahan dalam mengikuti perkembangan zaman yang salah satunya mengenai pola pemerintahan yang awalnya sentralistik menjadi desentralisasi pada tahun 1999. Sejarah perubahan pola pemerintahan ini diawali oleh jatuhnya negara-negara dengan bentuk negara kesatuan pola sentralistik. Tidak berfungsi dan gagalnya sistem pembuatan keputusan yang sentralistis, di mana pemerintah pusat tidak dapat menyediakan solusi-solusi bagi tiap-tiap komunitas di tiap-tiap daerah yang beragam serta berawal dari kesadaran akan kebutuhan manajemen bahwa mengelola negara secara sentralistik dengan seribu satu macam permasalahan pemerintahan jelas tidak efektif dan melelahkan menjadi latar belakang dan asal muasal reformasi desentralisasi serta memunculkan tuntutan kebijakan otonomi daerah. ${ }^{1}$

\footnotetext{
${ }^{1}$ Rudy, Hukum Pemerintahan Daerah Perspektif Konstitusionalisme Indonesia, (Bandar Lampung: Indepth Publishing, 2012), hlm. 19.
} 
Ian Johnson" menyatakan bahwa “...starting in the mid-1980s, governments worldwide began decentralizing some responsibilities, decision making authority and resources to intermediate and local governments and often to communities and the private sector.."..

Beliau menyatakan bahwa desentralisasi telah dimulai sejak awal 1980-an. Kemudian dia menyatakan "...its implications for economic growth, poverty alleviation and the development of civil society and democratic institutions". 3 Dengan pernyataan tersebut merupakan penegasan akan pentingnya desentralisasi dalam pertumbuhan ekonomi, pengentasan kemiskinan, dan perkembangan rakyat sipil dan institusi demokrasi.

Gejolak yang dialami oleh bangsa Indonesia semenjak kejatuhan Asian Miracles ${ }^{4}$ akibat krisis ekonomi di Thailand yang berdampak pada negara-negara di kawasan Asia, termasuk Indonesia menimbulkan suatu gagasan untuk memasukan prinsip desentralisasi dan otonomi daerah dalam pola pemerintahan yang selama ini sentralistik.

"Diawali dengan proses amandemen UUD 1945 termasuk dalam ketentuan mengenai pemerintahan daerah, pemerintahan merespon kepada permintaan akan desentralisasi yang semakin keras ketika DPR dengan cepat menyetujui dua undang-undang pada April 1999 dengan menetapkan tanggal 1 Januari 2001 sebagai waktu dimulainya pelaksanaan desentralisasi yang drastis, yang bisa dikatakan big bang". 5

Desentralisasi sebagai salah satu prinsip dasar penyelenggaraan pemerintahan yang merupakan kebalikan dari sentralisasi dimana dalam sistem pemerintahan sentralisasi, kewenangan pemerintah baik di pusat maupun di daerah dipusatkan dalam tangan pemerintah pusat. Pejabatpejabat di daerah hanya melaksanakan kehendak pemerintah pusat. Sedangkan dalam sistem desentralisasi, sebagian kewenangan pemerintah pusat dilimpahkan kepada pihak lain untuk dilaksanakan. Pelimpahan kewenangan pemerintah kepada pihak lain untuk dilaksanakan disebut desentralisasi. ${ }^{6}$

\footnotetext{
2 James Manor, The Political Economy of Democratic Desentralization, (Washington, D. C.: The World Bank, 1999), hlm. 8.

${ }^{3}$ Ibid, hlm. 9.

${ }^{4}$ Asian Miracles merupakan istilah yang sangat terkenal mengenai kesuksesan negara kesatuan sentralistik di Asia dimana negara-negara ini dengan sistem kekuasaan terpusat dapat meningkatkan pertumbuhan ekonomi yang sangat tinggi. Namun demikian, krisis ekonomi di Asia menyebabkan runtuhnya tesis menganai Asia Miracles yang menyisakan negara-negara Jepang sebagai negara yang masih menjadi kekuatan ekonomi di Asia. Baca Rudy, Hukum Pemerintahan ...Op.Cit., hlm. 15.

${ }^{5}$ Ibid.

${ }^{6}$ Ibid, hlm. 16.
} 
Lebih jauh lagi Rondinelli ${ }^{7}$ secara tegas menyatakan bahwa desentralisasi merupakan:

"the transfer or delegation of legal and authority to plan, make decisions and manage public functions from the central governmental its agencies to field organizations of those agencies, subordinate units of government, semi authonomous public coparation, area wide or regional development authorities; functional authorities, authonomous local govenment, or nongovernmental organizations".

Dengan mendesentralisasikan kewenangan-kewenangan dari pemerintah pusat kepada pemerintah daerah, daerah berwenang untuk menjalankan tugas dan urusan-urusan tertentu yang diserahkan oleh pemerintah pusat kepada pemerintah daerah untuk diselenggarakan sesuai dengan kebijaksanaan, prakarsa, dan kemampuan daerah. ${ }^{8}$ Jadi, adanya penyerahan kewenangan di bidang tertentu secara vertikal dari institusi/lembaga/pejabat kepada bawahannya, maka yang diserahi atau dilimpahi wewenang tertentu tersebut berhak bertindak atas nama sendiri dalam urusan tersebut. ${ }^{9}$

Otonomi daerah yang diberikan oleh pemerintah pusat, setidaknya harus melingkupi 3 (tiga) asas hak asal-usul yaitu: pengakuan terhadap susunan asli, pengakuan terhadap sistem norma/pranata sosial yang dimiliki dan berlaku, serta pengakuan terhadap basis material yakni hak ulayat serta aset-aset kekayaan desa (property right). ${ }^{10}$

Berlakunya konsep desentralisasi di Indonesia, kekuasaan atau kewenangan oleh pemerintah pusat untuk mengurus berbagai kepentingan masyarakatnya diberikan kepada daerah-daerah untuk menjalankan tugas pemerintahan, yang berarti bahwa, pemerintah di daerah diberikan kewenangan untuk mengurus sendiri daerahnya dengan prinsip otonomi. Otonomi pemerintah daerah banyak bergantung pada pemerintah pusat, yaitu sampai sejauh mana pemerintah pusat mempunyai niat baik untuk memberdayakan pemerintah daerah melalui pemberian wewenang yang lebih besar. Hal ini dikarenakan, dengan didesentralisasikannya kekuasaan dan kewenangan dari pusat kepada daerah dalam keadaan berlangsungnya otonomi akan sangat penting dalam mencapai tujuan desentralisasi itu sendiri.

\footnotetext{
${ }^{7}$ Ibid, hlm. 17

${ }^{8}$ Josef Riwu Kaho, Prospek Otonomi Daerah di Negara Republik Indonesia, (Rajawali Pers, 1991), hlm. 14.

${ }^{9}$ H. M. Busrizalti, Hukum Pemda Otonomi Daerah dan Implikasinya, (Yogyakarta: Total Media, 2012), hlm. 67.

${ }^{10}$ Rudy, Hukum Pemerintahan.Op.Cit, hlm. 103.
} 
Pelaksanaan desentralisasi diharapkan akan lebih membuka kesempatan bagi masyarakat untuk berpartisipasi dalam berbagai aktivitas politik di tingkat lokal. Masyarakat di daerah dapat dengan elegan mempraktekan bentuk-bentuk partisipasi politik, misalnya menjadi anggota partai politik dan kelompok kepentingan di samping mendapatkan kebebasan dalam mengekspresikan kepentingan dan aktif dalam proses pengambilan kebijakan. ${ }^{11}$ Jadi, mengamati pemaparan di atas dapat dilihat bahwa pentingnya partisipasi masyarakat lokal untuk mewujudkan desentralisasi tersebut merupakan salah satu tujuan dari relevansi gagasan otonomi daerah.

Adanya pemilihan umum sebagai wujud adanya partisipasi rakyat untuk ikut menentukan jalannya pemerintahan yang mencerminkan sebuah demokrasi yang baik. Sebagai prinsip dasar konstitusi, demokrasi dilaksanakan tidak hanya pada level penyelenggaraan pemerintahan pusat, tetapi juga diterapkan pada tingkat pemerintahan daerah. Dengan demikian, berbagai kebijakan, program, dan kegiatan yang dilakukan pemerintahan mewakili kehendak dan aspirasi masyarakat di daerah. Demokrasi tanpa partisipasi langsung oleh masyarakat merupakan bentuk pengingkatan terhadap demokrasi itu sendiri. Karena pada hakikatnya, instrumen pemilihan langsung mengandung nilai-nilai kebebasan, persamaan, dan kedaulatan rakyat yang menjadi prinsip demokrasi. ${ }^{12}$

\section{a. Pemilihan Umum Kepala Daerah}

Salah satu manifestasi utama demokrasi yaitu diinisiasikannya pemilukada untuk memilih Gubernur/Wakil Gubernur, Bupati/Wakil Bupati dan Walikota/Wakil Walikota sebagai pelaksanaan dari amanat UU Nomor 32 Tahun 2004 tentang Pemerintahan Daerah yang dianggap mampu mengekspresikan dan melembagakan kehendak rakyat yang berdasarkan pengakuan atas kedaulatan berada di tangan rakyat untuk memilih figur kepala pemerintah daerah yang menentukan perkembangan dan pembangunan daerah. Hal ini jelas dimuat dalam Pasal 18 ayat (4) UUD 1945 yang menyatakan "Gubernur, Bupati, dan Walikota masing-masing sebagai kepala pemerintahan daerah provinsi, kabupaten, dan kota dipilih secara demokratis".

Tujuan pilkada adalah terpilihnya kepala daerah dan wakil kepala daerah dan terselenggaranya pemerintahan yang sesuai dengan pilihan rakyat. Sesuai dengan muatan Pasal 59 ayat (1) UU Pemda yang membuka pencalonan pasangan kepala daerah melalui 3 (tiga) jalur, yakni:

\footnotetext{
${ }^{11}$ Abdul Malik Gismar dan Syarif Hidayat, Reformasi Setengah Matang, Penerbit Hikmah (Jakarta: PT Mizan Publika, 2010), hlm. 118.

12 Sartono Sahlan dan Awaludin Marwan, Nasib Demokrasi Lokal di Negeri Barbar, (Yogyakarta: Thafa Media, 2012), hlm. 71.
} 
1) partai atau gabungan $\operatorname{partai}^{13}$ yang memperoleh kursi di DPRD;

2) gabungan partai yang tidak memperoleh kursi di DPRD; dan

3) calon perseorangan yang mendapat sejumlah dukungan dari pemilih.

Mengingat demokrasi lokal merupakan salah satu substansi konstitusi, maka semua pihak bertanggung jawab untuk mendorong dan mengawal pelaksanaannya, termasuk penyelenggara pilkada. Salah satu sifat penting dari kelembagaan penyelenggara pilkada adalah sifat mandiri. Sifat mandiri berarti bebas dari segala bentuk pengaruh atau intervensi pihak lain, yang dapat mengurangi kemampuan penyelenggara pilkada dalam melaksanakan pilkada yang luber dan jurdil. ${ }^{14}$ Sifat mandiri juga sering disebut dengan sifat independen. Hanya dengan kemandirian penyelenggaralah, pelaksanaan pilkada yang jujur dan adil dapat dijamin. Upaya menjamin kemandirian penyelenggara pilkada dilakukan sejak proses rekrutmen, pelaksanaan tugas, hingga pertanggungjawaban. ${ }^{15}$ Penyelenggara pilkada, baik KPU provinsi dan KPU kabupaten/kota maupun Bawaslu dan Panwaslu, harus independen dalam menjalankan tugasnya masing-masing, sesuai dengan peraturan perundang-undangan. ${ }^{16}$

UU Penyelenggara Pemilu telah mengatur mengenai kewajiban dan tanggung jawab para penyelenggara pilkada yang terdiri atas Komisi Pemilihan Umum ${ }^{17}$ dan Badan Pengawas Pemilu ${ }^{18}$ serta Dewan Kehormatan Pemilu ${ }^{19}$ dengan berpegang teguh pada asas-asas ${ }^{20}$ mandiri, jujur, adil, kepastian hukum, tertib, kepentingan umum, keterbukaan, proporsionalitas, profesionalitas, akuntabilitas, efisiensi, dan efektivitas.

Terselenggaranya pilkada yang bersifat langsung, umum, bebas, rahasia, jujur, dan adil hanya dapat terwujud apabila penyelenggaranya

\footnotetext{
${ }^{13}$ Parpol mempunyai 4 (empat) fungsi penting dalam negara demokrasi modern, yaitu: (1) sebagai sarana politik, (2) sebagai sarana sosialisasi politik, (3) sebagai sarana rekrutmen politik, (4) sebagai sarana pengatur konflik. Baca Abdul Mukhtie Fadjar, Partai Politik dalam Perkembangan Ketatanegaraan Indonesia, Setara Press, Malang, 2012, hlm. 18-19.

${ }^{14}$ Ibid, hlm. 109.

${ }^{15}$ Ibid.

${ }^{16}$ Ibid, hlm. 111.

17 Pasal 1 angka 6 UU Penyelenggara Pemilu berisikan "Komisi Pemilihan Umum, selanjutnya disingkat KPU adalah lembaga penyelenggara pemilu yang bersifat nasional, tetap, dan mandiri yang bertugas melaksanakan pemilu".

18 Pasal 1 angka 16 UU Penyelenggara Pemilu berisikan "Badan Pengawas Pemilu, selanjutnya disingkat Bawaslu adalah lembaga penyelenggara pemilu yang bertugas mengawasi penyelenggaraan pemilu di seluruh wilayah Negara Kesatuan Republik Indonesia (NKRI)"

${ }^{19}$ Pasal 1 angka 22 UU Penyelenggara Pemilu berisikan "Dewan Kehormatan Penyelenggara Pemilu, selanjutnya disingkat DKPP adalah lembaga yang bertugas menangani pelanggaran kode etik penyelenggara pemilu dan merupakan satu kesatuan fungsi penyelenggaraan pemilu".

${ }^{20}$ Pasal 2 UU tentang Penyelenggara Pemilu.
} 
mempunyai integritas yang tinggi serta memahami dan menghormati hakhak sipil dan politik dari warga negara.

\section{b. Pemilihan Gubernur Lampung}

Provinsi Lampung terletak di ujung selatan Pulau Sumatera yang merupakan pintu gerbang lalu lintas antara Pulau Sumatera dengan Pulau Jawa. Penduduk Lampung berjumlah 7,6 juta jiwa yang merupakan jumlah terbesar ke-2 di Pulau Sumatera. Dari sisi administratif pemerintahan, Lampung terdiri dari 12 kabupaten dan 2 kota. Luas wilayah daratan $35.367,5 \mathrm{~km}^{2}$, daratan dan perairan $51.991 .0 \mathrm{~km}^{2}$.

Hingga saat ini lampung telah berganti pemimpin sebanyak 11 kali masa pemerintahan di antaranya yaitu:

1) Kusno Danupoyo, merupakan Gubernur Lampung pertama yang menjabat pada tahun 1964-1966;

2) Zainal Abidin Pagaralam, menjabat pada tahun 1966-1973;

3) R. Sutiyoso, menjabat pada tahun 1973-1978;

4) Yasir Hadibroto, menjabat pada tahun 1978-1988;

5) Kolo Poedjono Pranyoto, menjabat pada tahun 1988-1993;

6) Kolo Poedjono Pranyoto, menjabat pada tahun 1993-1998;

7) Oemarsono, menjabat pada tahun 1998-2003;

8) Tursandi Alwi, menjabat pada tahun 2003-2004 (Pejabat Gubernur);

9) Sjachroedin Z.P , menjabat pada tahun 2004-2008;

10) Syamsurya Ryacudu, menjabat pada tahun 2008-2009;

11) Sjachroedin Z.P, menjabat pada tahun 2008-2014; dan

12) M. Ridho Ficardo, menjabat pada tahun 2014-2019.

Sebuah pelajaran penting dalam pelaksanaan pemilihan umum kepala daerah umumnya dan kepala daerah Lampung khususnya adalah pelaksanaan pemilihan umum kepala daerah periode 2014-2019.

Komisi Pemilihan Umum Daerah (KPUD) Provinsi Lampung sesuai dengan tugas dan fungsinya sebagai penyelenggara pemilukada ingin menggelar Pemilukada pada tahun 2013.

Dasar yang menjadi KPUD Provinsi Lampung akan menyelenggarakan Pemilukada tahun 2013 di dasarkan terhadap pemahaman ketentuan Pasal 86 ayat (1) UU No. 32 Tahun 2004 tentang Pemerintah Daerah. Pasal 86 ayat 1 UU No. 32 Tahun 2004 menyatakan bahwa pemungutan suara, pemilihan pasangan calon kepala daerah dan wakil kepala daerah diselenggarakan paling lambat 1 (satu) bulan sebelum masa jabatan kepala daerah berakhir. Artinya pelaksanaannya dapat dimajukan tanpa mengurangi masa jabatan kepala daerah. Bahkan makna dalam pasal 86 ayat 1 UU No. 32 Tahun 2004 bisa dilaksanakan setahun sebelumnya, selagi tidak sampai pada berakhirnya masa jabatan kepala daerah dan wakil kepala daerah karena dalam proses pelaksanaan pemilukada memerlukan 
waktu yang sangat lama. Oleh karena itu, penjadwalan KPUD dalam menyelenggarakan pemilukada pada tahun 2013 sudah sangat tepat mengingat waktu yang dibutuhkan dalam pelaksanaan membutuhkan waktu yang sangat lama dari proses persiapan hingga proses pelaksanaan.

Rencana pelaksanaan pemilukada yang ditetapkan oleh KPUD Provinsi Lampung mendapatkan penolakan dari pihak Kepala Daerah/Gubernur Lampung yaitu Sjachroedin ZP, Pemilukada tidak bisa berjalan tanpa adanya dukungan dari Gubernur/Pemerintah Provinsi, mengingat dasar anggaran pemilukada Pasal 114 ayat (5) UU No. 22 Tahun 2007 tentang Penyelenggara Pemilihan Umum menyebutkan bahwa pendanaan penyelenggaraan Pemilu Kepala Daerah dan Wakil Kepala Daerah wajib dianggarkan dalam Anggaran Pendapatan dan Belanja Daerah (APBD). Gubernur lampung belum bersedia/menolak jika pemilukada diadakan pada tahun 2013 dengan alasan tidak adanya anggaran. ${ }^{21}$

Perkembangannya dalam Kementrian Dalam Negeri (Kemendagri) mendesak Pemerintah Provinsi Lampung untuk segera mengalokasikan penganggaran pemilihan Gubernur, sehingga pesta demokrasi di daerah itu dapat digelar sebelum Pemilu 2014. Maka berdasarkan fakta data tersebut kunci penyelenggaraan pemilukada itu terletak pada anggaran.

Dari beberapa dekade palaksanaan pemerintahan Kepala Daerah Lampung. Untuk pertama kalinya dalam masa sejarah Lampung, pelaksanaan pemilihan gubernur yang ditundasampai tiga kali masa, yakni:

1) tanggal 2 Oktober 2013; kemudian dimundurkan

2) tanggal 2 Desember 2013, diundur lagi

3) tanggal 27 Februari 2014; kemudian dimundurkan lagi

4) tanggal 9 April 2014.

\section{Evaluasi Pemilihan Umum Provinsi Lampung Tahun 2014 a. Kapasitas KPUD Lampung}

KPUD selaku penyelenggara Pemilukada. UU No. 32 Tahun 2004 tentangPemerintah Daerah, mengatur tentang penyelenggara Pemilukada. Penyelenggara pemilihan kepala daerah dilaksanakan oleh KPUD. Dalam hubungan ini, KPUD direpresentasikan sebagai instansi yang tugasnya menyelenggarakan pemilu yang bebas, mandiri, demokratis, dan transparan dengan asas langsung, umum, bebas, rahasia, jujur, dan adil di daerah.

Pertama kalinya dalam masa sejarah pelaksanaan pemilihan umum Provinsi Lampung, pelaksanaan pemilihan gubernur yang ditunda sampai tiga kali masa yakni tanggal 2 Oktober 2013, disebabkan oleh alasan tidak adanya anggaran pada APBD 2013 ditunda pada tangga 12 Desember 2013, disebabkan oleh alasan tidak adanya dana, kemudian tanggal 27 Februari

\footnotetext{
${ }^{21}$ Lampung Post, Gubernur tolak Pilgub, 29 Agustus 2013.
} 
2014, kemudian dimundurkan lagi tanggal 9 April 2014. Umumnya penundaan pelaksanaan pemilihan gubernur ini disebabkan oleh tidak adanya dana dalam APBD 2013 untuk pelaksanaan pemilihan umum kepala daerah/gubernur Lampung.

\section{b. Waktu Pelaksanaan}

Waktu pelaksanaan pemilihan umum ini telah mengalami beberapa kali pengunduran, di antaranya pada tanggal tanggal 2 Oktober 2013, dimundurkan tanggal 2 Desember 2013, diundur tanggal 27 Februari 2014, kemudian dimundurkan lagi dan pada akhirnya dilaksanakan pada tanggal 9 April 2014.

Dalam penyelenggaraan pemilukada dasar hukum untuk menyelenggarakan pemilukada yaitu Pasal 86 ayat (1) UU No. 32 Tahun 2004 tentang Pemerintah Daerah, menyatakan bahwa pemungutan suara, pemilihan pasangan calon kepala daerah dan wakil kepala daerah diselenggarakan paling lambat 1 (satu) bulan sebelum masa jabatan kepala daerah berakhir. Berdasarkan pemahaman makna dalam Pasal 86 ayat (1) UU 32 Tahun 2004 tentang Pemerintah Daerah yaitu:

1) pelaksanaannya pemilukada dapat dimajukan tanpa mengurangi masa jabatan kepala daerah jadi, jika pelaksanaan pemilukada diadakan 1 (satu) tahun sebelum masa jabatan kepala daerah dan wakil kepala daerah habis itu sah-sah saja tidak ada masalah atau melanggar hukum pemilukada; dan

2) percepatan pelaksanaan pemilukada tidak akan memangkas masa jabatan incumbent. Landasan hukum pemilukada sudah sangat jelas, tegas, dan terperinci. Pemilukada, dilakukan sekali dalam lima tahun merujuk pada UU 32 Tahun 2004 tentang Pemerintah Daerah Pasal 86 ayat (1), mengatakan pemilihan kepala daerah diselenggarakan paling lambat satu bulan sebelum masa jabatan berakhir. Artinya, pelaksanaan pemungutan suara dapat dimajukan lebih dari satu bulan bahkan lebih. Dengan syarat, masa jabatan kepala daerah incumbent tidak dikurangi. Kepala daerah yang terpilih dalam pemilukada mesti menunggu pelantikan sampai habis masa jabatan kepala daerah terdahulu.

Akibat multitafsir dalam pasal tersebut sehingga rencana pelaksanaan pemilukada yang ditetapkan oleh KPUD Provinsi Lampung mendapatkan penolakan dari berbagai pihak terutama Kepala Daerah/Gubernur, Pemilukada tidak bisa berjalan tanpa adanya dukungan dari Gubernur/Pemerintah Provinsi, mengingat dasar anggaran pemilukada Pasal 114 ayat (5) UU No. 22 Tahun 2007 tentang Penyelenggara Pemilihan Umum menyebutkan, bahwa pendanaan penyelenggaraan Pemilihan Umum Kepala Daerah dan Wakil Kepala Daerah wajib dianggarkan dalam APBD. 


\section{c. Biaya Pelaksanaan}

Biaya pemilihan Gubernur Lampung diperkirakan mencapai Rp. 300 Miliar, yaitu untuk pembiayaan pemilihan Gubernur yang ditangani KPUD Lampung sebesar Rp. 187 Miliar, Bawaslu Rp. 64 Miliar, dan sisanya untuk biaya pengamanan ditangani pihak kepolisian dan instansi terkait yang dimaksud dengan biaya Pemilukada itu sendiri harus diklarifikasi terlebih dahulu definisinya. Ada tiga kategori biaya yang sering dianggap sebagai biaya Pemilukada,di antaranya:

a. biaya penyelenggaraan pemilukada; dan

b. biaya yang dikeluarkan untuk partai politik (dalam praktiknya ialah biaya yang dikeluarkan untuk dapat dicalonkan oleh partai politik). Biaya yang dikeluarkan untuk keperluan kampanye Pemilukada.

Berkaca dari pelaksanaan pemilihan umum Provinsi Lampung pada tanggal 9 April 2014 dilakukan penundaan disebabkan tidak adanya dana untuk pelaksanaan pemilihan kepala daerah. Hal ini disebabkan oleh pendanaan terhadap pelaksanaan pemilihan ini berada di dalam APBD. Pemilukada Lampung ditunda dikarenakan tidak adanya dana untuk pelaksanaan pemilihan umum. Mengingat dasar anggaran Pemilukada Pasal 114 ayat (5) UU No. 22 Tahun 2007 tentang Penyelenggara Pemilihan Umum menyebutkan bahwa pendanaan penyelenggaraan Pemilihan Umum Kepala Daerah dan Wakil Kepala Daerah wajib dianggarkan dalam APBD.

Sebuah insiatif bergulir untuk mengantisipasi hal yang sama terjadi kedua kalinya maka Komisi Pemilihan Umum Daerah (KPUD)harus independen dalam hal pendanaan penyelenggaraan pemilihan umum kepala daerah. KPUD harus mampu untuk mandiri dan tidak menggantungkan diri pada kemurahan hati pemerintah daerah. Anggaran untuk pelaksanaan pemilihan umum kepala daerah tersebut seharusnya berada di KPU RI bukan berada di Pemerintah Daerah.

\section{Penutup}

Pelaksanaan pemilihan umum di Provinsi Lampung pada tanggal 9 April 2014 menyimpan sebuah bahan pengoreksian. Bahan pengoreksian tersebut terletak pada Kapasitas KPUD Lampung, waktu pelaksanaan dan biaya pelaksanaan. Ketiga aspek tersebut sangat erat satu sama lain dan saling mempengaruhi satu sama lain.

Koreksi mendalam dari pelaksanaan pemilihan umum kepala daerah Provinsi Lampung pada tanggal 9 April 2014 adalah terletak pada penundaan pelaksanaan pilgub Lampung yang telah tiga kali dilakukan penundaan. Umumnya penundaan pelaksanaan tersebut disebabkan oleh tidak adanya dana untuk pelaksanaan pemilihan umum. 
Persoalan dana inilah berdampak langsung terhadap pelaksanaan pilgub Lampung. Menanggulangi hal tersebut, KPUD harus independen dalam hal dana pelaksanaan pemilihan kepala daerah tanpa harus menunggu belas kasihan dari Pemerintah Daerah.

\section{Daftar Pustaka}

\section{A. Buku}

Gismar, Abdul Malik, dan Syarif Hidayat, 2010. Reformasi Setengah Matang, Jakarta: Penerbit Hikmah PT Mizan Publika.

Kaho, Josef Riwu, 1991. Prospek Otonomi Daerah di Negara Republik Indonesia, Rajawali Pers.

Manor, James, 1999. The Political Economy of Democratic Desentralization, Washington DC:The World Bank.

Rudy, 2012. Hukum Pemerintahan Daerah Perspektif Konstitusionalisme Indonesia, Bandar Lampung: Indepth Publishing.

Sahlan, Sartono, dan Awaludin Marwan, 2012. Nasib Demokrasi Lokal di Negeri Barbar, Yogyakarta: Thafa Media.

\section{B. Peraturan Perundang-Undangan}

Undang-Undang Dasar Negara Republik Indonesia Tahun 1945.

UU Nomor 15 Tahun 2011 tentang pokok Penyelenggara Pemilihan Umum.

Undang-Undang Nomor 32 Tahun 2004 tentang Pemerintahan Daerah.

\section{Lain-lain}

Lampung Post, Gubernur tolak Pilgub, 29 agustus 2013. 